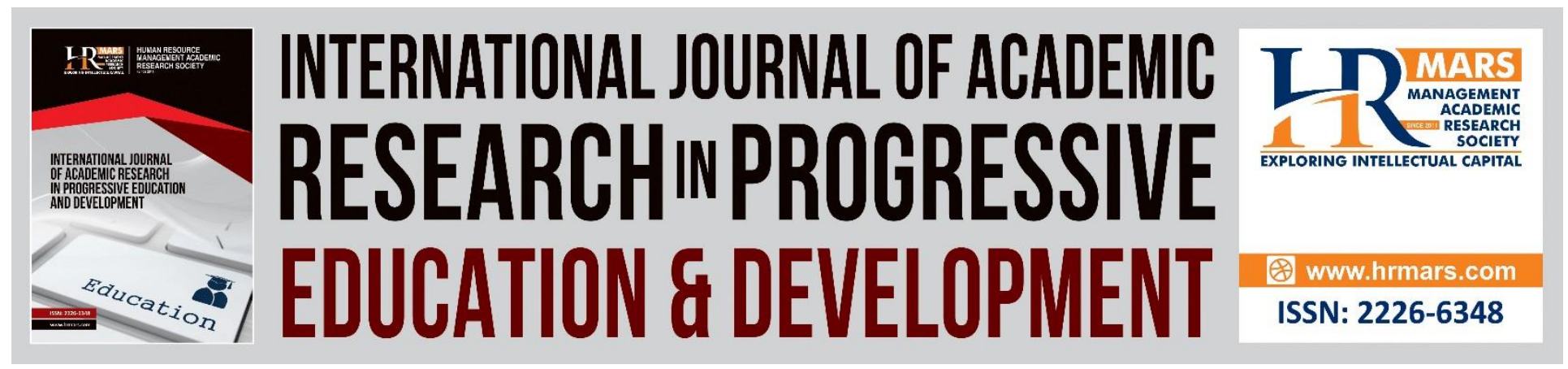

\title{
The Effectiveness of Colour-Coded Dominoes in Enhancing Simple Sentence Construction
}

Dharshini Krishnan Morthy, Azlina Abdul Aziz

To Link this Article: http://dx.doi.org/10.6007/IJARPED/v10-i1/8391

DOI:10.6007/IJARPED/v10-i1/8391

Received: 03 December 2020, Revised: 01 January 2021, Accepted: 17 January 2021

Published Online: 10 February 2021

In-Text Citation: (Morthy \& Aziz, 2020)

To Cite this Article: Morthy, D. K., \& Aziz, A. A. (2020). The Effectiveness of Colour-Coded Dominoes in Enhancing Simple Sentence Construction. International Journal of Academic Research in Progressive Education and Development, 10(1), 1-12.

Copyright: (C) 2021 The Author(s)

Published by Human Resource Management Academic Research Society (www.hrmars.com)

This article is published under the Creative Commons Attribution (CC BY 4.0) license. Anyone may reproduce, distribute, translate and create derivative works of this article (for both commercial and non-commercial purposes), subject to full attribution to the original publication and authors. The full terms of this license may be seen at: http://creativecommons.org/licences/by/4.0/legalcode

Vol. 10(1) 2021, Pg. 1 - 12

http://hrmars.com/index.php/pages/detail/IJARPED JOURNAL HOMEPAGE

Full Terms \& Conditions of access and use can be found at http://hrmars.com/index.php/pages/detail/publication-ethics 


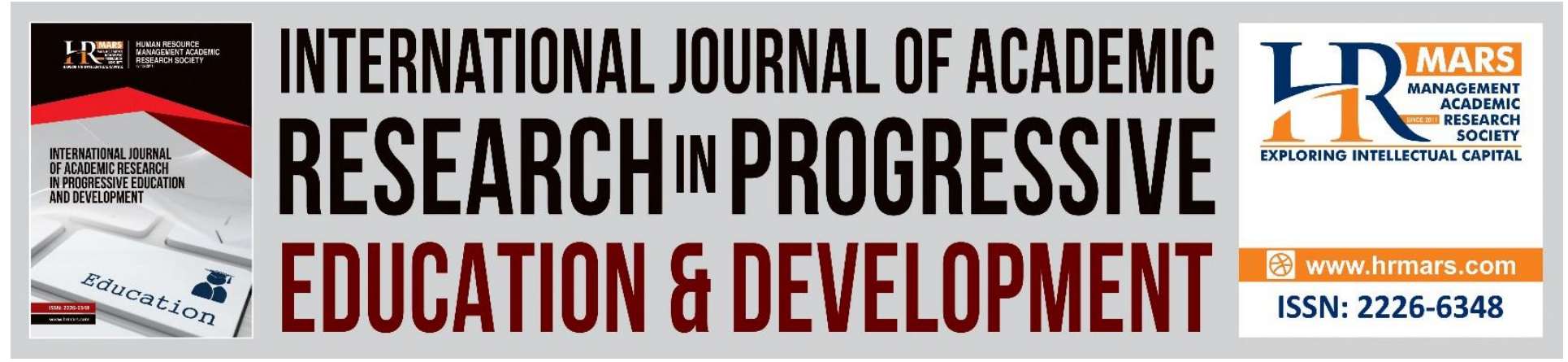

\title{
The Effectiveness of Colour-Coded Dominoes in Enhancing Simple Sentence Construction
}

\author{
Dharshini Krishnan Morthy, Azlina Abdul Aziz \\ Faculty of Education, Universiti Kebangsaan Malaysia (UKM), 43600 Bangi, Selangor, Malaysia \\ Email: dharsh5krish@gmail.com, azlina1@ukm.edu.my
}

\begin{abstract}
Writing is considered one of the most arduous language skills to master by English as a Second Language (ESL) learners. Hence, this study aims to investigate the effectiveness of colour-coded Dominoes in enhancing simple sentence construction among year three pupils. Twenty pupils from a national school in Johor Bahru district who had obtained Band 2 in School-Based Assessment (SBA) were selected as the participants of this action research. The data were collected through pre-test, post-test, Focus Group Interview (FGI) and field notes on classroom observation. The findings revealed that colour-coded Dominoes had enhanced simple sentence construction among the participants effectively. This study has impacted the pupils by elevating their learning motivation in a fun and conducive learning atmosphere with its attractive features to construct simple sentences. Thus, language games such as colour-coded Dominoes should be incorporated into English lessons to facilitate teaching and learning.
\end{abstract}

Keywords: Colour-Coded Dominoes, ESL Learners, Language Games, Simple Sentence Construction, Writing Skill

\section{Introduction}

Every child in Malaysia is assured of achieving a hundred percent basic literacy in English language along with the national language after the first three years of primary schooling (Malaysian Education Blueprint 2013-2025). Our Ministry of Education's (MoE) launch of the English Language Education Reform in Malaysia: The Roadmap 2015-2025 is an indication of the nation's determination to bring about substantial improvement in our students' proficiency in the English language. However, despite all the efforts initiated by the government, English proficiency in Malaysia is dwindling (May \& Said, 2019) especially in writing skills (len et al., 2017).

The process of acquiring the writing skill is by no means easy (len et al., 2017). Our former education director-general, Khair Mohamad Yusof stated that our pupils have yet to achieve a level desired for writing in the English Language as 23 percent of pupils had failed in their English written paper in the Malaysian Primary School Achievement Test in 2016 ("New UPSR", 2016). He also added that the two papers revealed the pupils' weakness in writing accurate and 
grammatically-correct answers. This is further supported by Cole and Feng (2015) who claimed that primary ESL learners have difficulties in acquiring writing skill which is decoded as the most arduous component of the language due to the lack of grasp on organizing ideas, choosing the precise lexical and employment of correct grammar. This shows that there has been an extensive performance gap between the expectation outlined by the MoE in the Malaysian Education Blueprint 2013 - 2025 and primary school pupils' capability to construct simple sentences that are grammatically correct.

$\mathrm{Li}$ and Yee (2017) conducted congruent study concerning strategies in conquering writing problems among pupils in urban primary school. They asserted that pupils were reluctant to learn the language due to the teaching methods employed by the teachers and the unconducive learning atmosphere. Teachers' way of teaching which suits the pupils' learning styles is much preferred as this will heighten their learning motivation to improve in ESL writing (Li \& Razali, 2019). When the teachers fail to exert precise teaching strategy, they eventually fail to create a non-threatening learning environment to boost pupils' motivation and attract their interest in grasping the language. Chambers and Yunus (2017) also carried out a study on the writing problems among pupils in a rural area of Sarawak. They claimed that the mother tongue interference acts as a hindrance to the pupils' learning.

Many past studies were carried out to investigate the effectiveness of language games on sentence construction among upper primary pupils (Li \& Yee, 2017; Lau et al., 2019; Ling \& Mohamad, 2018; Miin et al., 2019; Jusun \& Yunus, 2016; len et al., 2017; May \& Said, 2019) and secondary school students (Chambers \& Yunus, 2017). Hence, studies are yet to be done on the lower primary pupils. Therefore, this study aspires to bridge the gap by contributing meaningful insights on the use of language games in enhancing sentence construction particularly among lower primary pupils. It is significant too as it maximizes a new teaching approach concerning the simple sentence construction from building positive perception and interest towards English writing with hands-on learning among the lower primary pupils.

This study aims to determine the effectiveness of colour-coded Dominoes in enhancing simple sentence construction among the low-intermediate proficient year three pupils. The following research questions were formulated in order to facilitate the study:

- To what extent does colour-coded Dominoes enhance the low-intermediate proficient year three pupils in constructing simple sentences?

- How does the use of colour-coded Dominoes enhance the low-intermediate proficient year three pupils in constructing simple sentences?

This article instigates with a brief introduction of the topic, continues with the literature review, methodology, findings, discussion, conclusion, implications and recommendations for future research.

\section{Literature Review}

\section{Simple Sentence Construction}

Writing is a form of communication that enable learners to divulge their feelings and ideas through a well-devised text. It is widely regarded as a critically paramount skill in the teaching and learning of English as a Second Language (ESL). It aids to solidify all other language skills of listening, speaking and reading (Saed \& AL-Omari, 2014) as it is a comprehensive skill that 
enhances vocabulary, grammar, thinking, planning, editing, revising and other elements (len et al., 2017).

In addition, writing is considered as one of the most arduous language skills learners are anticipated to master (Majid et al., 2015) since it provokes intellectual growth. Learners bridge their prior knowledge with new information and fine-tune their ideas (Singh, 2014) to express themselves victoriously in the process of writing. Hence, it is crucial to master the skill of sentence construction in order to create a piece of writing that is meaningful.

Simple sentence construction that adhered to the Subject - Verb - Object (SVO) rule (Chambers \& Yunus, 2017) is the fundamental aspect that pupils need to master by the first three years of primary schooling. When they failed to do it, they tend to have more complex problems in regards to writing as during year four they are required to write stories and articles (Miin et al., 2019).

\section{Colour-Coded Strategy}

Colour is regarded as an incredibly powerful tool in aiding learners to learn (Walker-Gleaves \& Waugh, 2017). It is capable of creating a more productive and happy learning atmosphere by employing learners' visual-spatial intelligence. Decoding language will be faster with the presence of colours as it provokes memories and assists them in building associations (Devine, 2014). Furthermore, Geigle (2014) asserted that colour helps in raising productivity in a classroom as it can boost learners' attention span. He also affirmed that colours succour learners in their attempt to master writing skill by distinguishing, remembering and conveying information that results in meaningful learning.

Correspondingly, Sahathevan and Yamat (2020) found in their study that colour-coded Jenga blocks aid learners to understand, encode and decode the information concerning sentence structure as well as grammar rules through a plain sailing. The repetitive rearranging activity with the blocks enabled the learners to link the sentence components with specific colours, reimagine them in their mind and provides them with finer retention and comprehension of the grammar rules and structure of simple sentence taught in a risk-free environment. Devine (2014) added that divergent colours aid learners in differentiating the subdivisions of a sentence. Colour also act as scaffolding constituent that could ease the learners in distinguishing the components in a sentence (Gregory \& Herndon, 2010). The learnt experiences and generalisations will reduce the learners' anxiety in acquiring the writing skill. Therefore, the colour-coding strategy is a reliable tool which will help introduce the components of a sentence and to construct simple sentences by ESL learners.

\section{Colour-Coded Dominoes}

The growing vogue of games has triggered greater interest in the employment of games for teaching and learning (Dickey, 2015). Yaccob and Yunus (2019) defined the language game as an activity that is used to facilitate the learning of a language. It differs from entertainment games as it has defined learning outcomes to be met. Felicia (2014) asserted that game-based learning offers a risk-free context where learners can make mistakes, actively learn and practice the subject matter through experimentation. It also will be an alternative platform for the learners to seek knowledge and comprehend the subject matter being taught. 
A language game is fruitful to the learners in various ways. Goodman and Goodman (2014) asserted that "children learn language best in an environment rich with opportunities to explore interesting objects and ideas" (p.197). In this context, games are assured to be beneficial (Taheri, 2014) as it creates an interesting and fun learning atmosphere. In other word, language games act as a platform for learners to acquire the target language actively in a non-threatening learning environment.

Domino is a non-digital language game. It is a game of physical and mental skill, built on the small rectangular blocks ("Collins English Dictionary", 2018). In this study, Dominoes were maximized by coding five different colours to depict the parts of the sentences; green (object), pink (plural verbs), yellow (singular verbs), black (plural subject) and blue (singular subject). Studies by Sahathevan and Yamat (2020); Li and Yee (2017); Lau et al. (2019); Miin et al. (2019) and Jusun and Yunus (2016) had been focussing widely on subject, verb and object in general. However, this study intended to narrow the focus into singular subjects, plural subjects, singular verbs, plural subjects and objects respectively. This is deemed necessary as pupils are often found to be uncertain in choosing the right subject, verb and object in constructing sentences as claimed by Ghabool et al. (2012).

\section{Methodology}

This study employs action research since the problem is detected by the teacher in the classroom. An action plan is devised and the teacher directly collected the data as well as reflected the entire process after analysing the data to improve teaching and learning as a continuous effort.

Purposive sampling was employed in this action research. Twenty pupils who obtained band two for their writing skill in School-Based Assessment (SBA) had been selected as the participants of this study. This is due to their low-intermediate proficiency level which indicates that they need teacher's assistance in constructing simple sentences.

The research instruments used were pre-test, post-test, field notes on classroom observation and focus group interview. In ensuring the validity and reliability of the study, the test paper and interview questions were reviewed on the aspects like clarity, redundancy, readability and completeness by the field expert. An independent inter-observer assisted the observation in eliminating the biases in judging the effectiveness of the lessons.

Table 1 below describes the stages of data collection. A paired two-sample t-test was conducted to compare the differences between the mean scores of the pre-test and post-test whilst thematic analysis was done towards the data gathered from the focus group interview and field notes. 
INTERNATIONAL JOURNAL OF ACADEMIC RESEARCH IN PROGRESSIVE EDUCATION AND DEVELOPMENT

Vol. 10, No. 1, 2021, E-ISSN: 2226-6348 @ 2021 HRMARS

Table 1 Stages of Data Collection

\begin{tabular}{|c|c|c|}
\hline Week 1 & Week 2 - 5 & Week 6 \\
\hline $\begin{array}{l}\text { Pre-test } \\
\text { Participants were asked to } \\
\text { answer the pre-test in the } \\
\text { classroom. }\end{array}$ & $\begin{array}{l}\text { Lessons with the use of } \\
\text { colour-coded Dominoes in } \\
\text { constructing simple } \\
\text { sentences. }\end{array}$ & $\begin{array}{l}\text { Post-test } \\
\text { Participants were given } \\
\text { post-test to determine the } \\
\text { changes or progress they } \\
\text { made in constructing } \\
\text { simple sentences after the } \\
\text { use of colour-coded } \\
\text { Dominoes. }\end{array}$ \\
\hline \multicolumn{3}{|c|}{$\begin{array}{l}\text { Focus Group Interview } \\
\text { Focus group interview was conducted at the end of the colour-coded Dominoes } \\
\text { lessons. }\end{array}$} \\
\hline Classroom Observations & & \\
\hline
\end{tabular}

\section{Findings}

1. To what extent does colour-coded Dominoes enhance the low-intermediate proficient year three pupils in constructing simple sentences?

Data from the pre-test and post-test were analysed in order to quantify RQ1. A paired twosample t-test was conducted in order to compare the differences between the mean scores of the pre-test and post-test using Statistical Package for the Social Sciences (SPSS) software.

Table 2 A paired two-sample t-test SPSS output

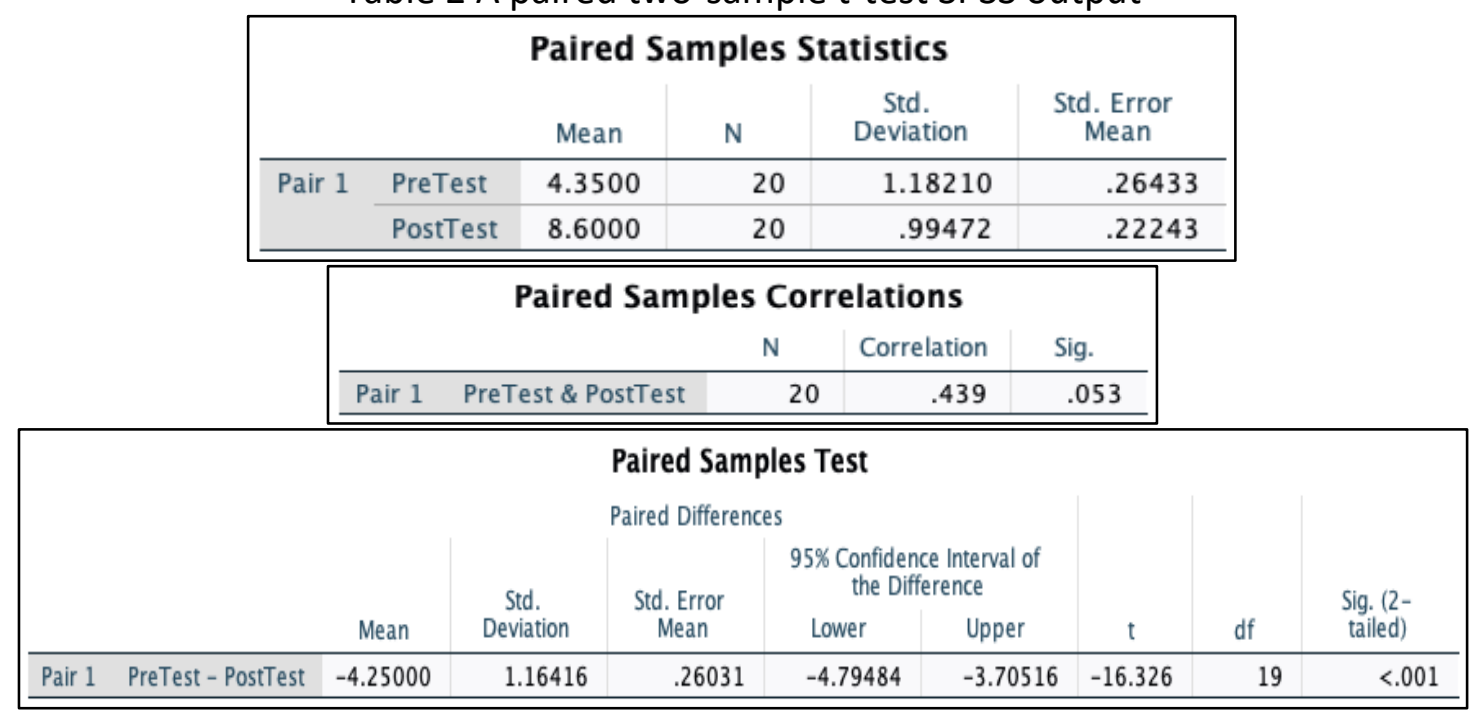


Vol. 10, No. 1, 2021, E-ISSN: 2226-6348 @ 2021 HRMARS

\begin{tabular}{|c|c|c|c|c|c|}
\hline \multicolumn{6}{|c|}{ Paired Samples Effect Sizes } \\
\hline & & \multirow[t]{2}{*}{ Standardizera } & \multirow{2}{*}{$\begin{array}{c}\text { Point } \\
\text { Estimate }\end{array}$} & \multicolumn{2}{|c|}{$95 \%$ Confidence Interval } \\
\hline & & & & Lower & Upper \\
\hline \multirow[t]{2}{*}{ PreTest - PostTest } & Cohen's d & 1.16416 & -3.651 & -4.876 & -2.412 \\
\hline & Hedges' correction & 1.18778 & -3.578 & -4.779 & -2.364 \\
\hline \multicolumn{6}{|c|}{$\begin{array}{l}\text { a. The denominator used in estimating the effect sizes. } \\
\text { Cohen's d uses the sample standard deviation of the mean difference. } \\
\text { Hedges' correction uses the sample standard deviation of the mean difference, plus a correction } \\
\text { factor. }\end{array}$} \\
\hline
\end{tabular}

As outlined in Table 2, there was a significant difference in the scores for pre-test $(\mathrm{M}=$ $4.35, \mathrm{SD}=1.18)$ and post-test $(\mathrm{M}=8.6, \mathrm{SD}=0.99)$ conditions; $\mathrm{t}(19)=-16.33, \mathrm{p}=<0.001(95 \% \mathrm{Cl}$ $=-4.795$ to -3.705$)$. The effect size of this analysis $(d=1.16)$ is larger than the assumptions of Cohen (1988). This reveals that colour-coded Dominoes enhanced the low-intermediate proficient year three pupils in constructing simple sentences.

How does the use of colour-coded Dominoes enhance the low-intermediate proficient year three pupils in constructing simple sentences?

To answer this research question, thematic analysis was conducted on the data gathered from the focus group interview and field notes from classroom observations. The classroom observations were carried out for two different ESL lessons by the researcher and the interobserver focussing on the pupils' attitude as well as participation. Those two lessons were labelled as L1 and L2. Focus group interview involved three participants (P3, P12, P17). Three themes were derived from the analysis of focus group interview and field notes; (a) Attractive features, (b) Motivation, and (c) Fun and conducive learning environment.

\section{a) Attractive Features}

Participants perceived the features of colour-coded Dominoes as attractive. When the nonparticipant observer probed the participants with the following question, "Why do you like learning using colour-coded Dominoes?", most of the participants referred to its features which are colourful and handy. This is evidenced from the following thread of interview response.

"I like Dominoes game, because it is colourful and easy to assemble." (P17, FGI)

During the observation, the researcher and the inter-observer noted that "the participants were actively participating to arrange the colour-coded Dominoes according to the words" (L1, L2). The feature of colour has attracted the attention of the participants in constructing sentences. This indicates that colours enabled the participants to erect mental connections between grammar rules and simple sentence construction (Devine, 2014). Colour which is beheld as an extremely powerful mechanism in learning (Walker-Gleaves \& Waugh, 2017) has also allowed the participants to exert their visual spatial intelligence which indirectly made the learning process easier and more meaningful.

Apart from that, the feature of game that has been incorporated into the study has played a pivotal role too. The participants claimed that they love playing colour-coded Dominoes game.

“...I like learning using colour-coded Dominoes game...."(P12, FGI)

It denotes that the feature of game has captivated and engaged the participants of this study (Felicia, 2014) to make mistakes, actively learn and practice the simple sentence construction. 
Vol. 10, No. 1, 2021, E-ISSN: 2226-6348 @ 2021 HRMARS

This risk-free context has also enabled the participants to retain the grammar rules longer by entailing hands-on practices.

\section{b) Motivation}

The participants were motivated with the use of colour-coded Dominoes in constructing simple sentences. This statement is excerpted from the focus group interview responses and classroom observations. Participants posited that they felt "motivated learning sentence construction through the use of colour-coded Dominoes as it has made the teaching and learning of sentence construction more meaningful" (P3, FGI). This has resulted in the participants to be more enthusiastic and eager compared to conventional method of teaching and learning in solving the task granted to them.

On the other hand, meaningful social interaction between the respective pairs in this study has motivated the participants constructively as can be seen from the field note:

"Some of the pupils were able to spot the mistakes done by their peers and correct it for them with little explanation. This improved pupils' motivation in learning and led a meaningful learning process to take place." (L1)

Accordingly, P12 claimed that it was easier to comprehend the grammar rules and arrange the colour-coded Dominoes accordingly in pairs as they could help and monitor each other.

"I feel comfortable when my friend correct my mistake. I understand better now." (P12, FGI)

The participants were able to learn more effectively with the assistance of their friends in a low stress environment for language practice. Learning ground would turned to be easier if the participants are given continuous support and guidance by their teacher or peers (Sahathevan \& Yamat, 2020). Thus, social interaction had boosted motivation to learn, facilitated discussions, knowledge transfer and created deeper sense of understanding (Tarantino et al., 2013) on the simple sentence construction with the use of colour-coded Dominoes.

\section{c) Fun and conducive learning atmosphere}

Another crucial perception put forth by the participants is colour-coded Dominoes has created a fun and conducive learning atmosphere. They felt less sleepy and "became more attentive in class" (L2). They also found the lesson with colour-coded Dominoes to be more fun, enjoyable and interesting which kept them to look forward towards the next lesson.

"I like learning using colour-coded Dominoes because, emm.. I get less sleepy in the class and it is not boring." (P12, FGI)

Furthermore, "the participants remained energetic from the beginning of the lesson until the end" $(L 1, L 2)$. The participants felt confident and excited the same time when their peers gave them positive feedbacks on their constructed sentences that cling to the SVO rule. This resulted the relationship among the participants to be strengthened. The participants also were not reprimanded for their mistakes instead it was considered as a platform for them to practice further. This indirectly promoted a conducive and non-threatening learning atmosphere.

It was evident that learning simple sentence construction through colour-coded Dominoes yields meaningful output by enhancing the low-intermediate proficient year three 
Vol. 10, No. 1, 2021, E-ISSN: 2226-6348 @ 2021 HRMARS

pupils' learning motivation and sentence construction in a fun yet conducive learning atmosphere with its' attractive features. Thus, second research question has been answered.

\section{Discussion}

Pupils' had positive perceptions towards the usage of colour-coded Dominoes in the classroom. It has encouraged them to acquire simple sentence construction in a more interesting manner. As observed, during the lessons, pupils communicated with their pairs to ensure they are functioning towards the common aim which was simple sentence construction that adhere to the SVO rule. Vygotsky's Social Constructivism Theory (1978) propounded social interaction as the fundamental element in learning. Pupils' experience in collaborating with their peers to resolve the task assigned enabled them in developing their skills that revamps their learning. Learners executed their tasks individually after working with more capable people who can scaffold them as emphasized in Vygotsky's social learning in the Zone of Proximal Development. This process enabled them to develop their communication and critical thinking skills. Simultaneously, pupils' social skills and intrapersonal skills were thrived too as they joined hands with their pairs and learnt to accept constructive criticism from them.

Colour-coded Dominoes offered a lot of attractive features for the pupils. As a result, they also attained several benefits, which include: grasping the grammar rules and construct simple sentences, having enjoyable and attentive lessons. These findings are aligned with Sahathevan and Yamat (2020). In the findings of their study, learners had positive perceptions towards the use of language game in learning simple sentence construction.

In the context of motivation, pupils felt that they were having a greater sense of purpose, thus becoming more engaged in the learning of simple sentence construction. This reflects the elements in Affective Filter Hypothesis under Krashen's Theory. Krashen (1981) postulated that "people acquire the second language only if they obtain comprehensible input and if their affective filters are low enough to allow the information in". Motivation, attitude, self-confidence and anxiety are under the 'affect' in his theory. The use of colour-coded dominoes prompted the learners to interact among their peers in a classroom which makes them to feel safe and secure without having people probing on their flaws. This lead the learners to not be afraid of committing mistakes as they are experiencing a low filter atmosphere. As a result, pupils get motivated to immerse in writing activities since colour-coded Dominoes acts as a tool that arouses their interest and enhances their sentence constructing skills in a risk-free environment.

Moreover, Toikka (2016) asserted that learners remember information longer if the learning demands physical movements such as hands-on practice as it bridges the parts of brain that initiate language learning and movement. Piaget's Cognitive Constructivism theory is align with it too. As the participants in this study attained the concrete stage, gaining knowledge by hands-on experience using colour-coded Dominoes was found to be fruitful for them. It could be seen through their improvements in the test scores after the 6 week lessons. The pupils could discern that their writing skill had enhanced remarkably. Hence, the findings of this study indicate that colour-coded Dominoes is effective in enhancing the low-intermediate proficient year three pupils in constructing simple sentences by lifting their learning motivation as well as creating a fun and conducive learning atmosphere with its attractive features. 
INTERNATIONAL JOURNAL OF ACADEMIC RESEARCH IN PROGRESSIVE EDUCATION AND

DEVELOPMENT

Vol. 10, No. 1, 2021, E-ISSN: 2226-6348 @ 2021 HRMARS

\section{Conclusion}

The use of colour-coded Dominoes does enhance simple sentence construction among the lowintermediate proficient year three pupils. Colour-coded Dominoes has managed to boost the participants' level of motivation by creating a non-threatening learning atmosphere through its attractive features.. It also has contributed to their improvement in simple sentence construction as can be seen from the scores in pre and post-tests.

\section{Implication}

The finding of the current study unveiled that the use of colour-coded Dominoes had enhanced the pupils in constructing simple sentences. Pupils benefitted from learning about simple sentence construction as they could interact explicitly and interrogate without feeling insecure to solve problems effectively with the assistance of their peers, the teacher and the colour-coded Dominoes in the classroom.

\section{Recommendations for Future Research}

The following is a recommendation that researchers might want to give a thought for future research. This study was focussing solely on a simple sentence construction. Therefore, it could be expanded by integrating different type of sentences like compound and complex sentences. Exposing pupils to different types of sentence writing could aid in enhancing their writing skills.

\section{References}

Chambers, G. J., \& Yunus, M. (2017). Enhancing Learners' Sentence Constructions via "Wheel of Grammar". Pertanika Journals Social Sciences \& Humanities ,25(4), 1641-1650. Cohen, J. (1988). Statistical Power Analysis for the Behavioral Sciences. 2nd Ed: Routledge.

Cole, J., \& Feng, J. (2015, April 20). Effective strategies for improving writing skills of elementary English Language learners. Retrieved from https://files.eric.ed.gov/fulltext/ED5561 23.pdf Collins English Dictionary. (2018). $13^{\text {th }}$ Ed. Glasgow: HarperCollins.

Devine, A. (2014). Colour Coding for Learners with Autism: A Resource Book for Creating Meaning through Colour at Home and School. London: Jessica Kingsley Publishers.

Dickey, M. D. (2015). Aesthetics and Design for Game-Based Learning. New York: Routledge.

Felicia, P. (2014). Game-Based Learning: Challenges and Opportunities. Newcastle: Cambridge Scholars Publishing.

Geigle, B. A. (2014). How Colour Coding Formulaic Writing Enhances Organization: A Qualititative Approach for Measuring Student Affect. California: Graduate Faculty of the Graduate Studies Department Humphreys College. https://files.eric.ed.gov/fulltext/ED554555.pdf

Ghabool, N., Mariadass, M. E., \& Kashef, S. H. (2012). Investigating Malaysian ESL Students' Writing Problems on Conventions, Punctuation and Language Use at Secondary School Level. Journal of Studies in Education, 2(3), 130-143. doi:10.5296/jse.v2i3.1892 
INTERNATIONAL JOURNAL OF ACADEMIC RESEARCH IN PROGRESSIVE EDUCATION AND

DEVELOPMENT

Vol. 10, No. 1, 2021, E-ISSN: 2226-6348 @ 2021 HRMARS

Goodman, K. S., \& Goodman, Y. M. (2014). Making Sense of Learners Making Sense of Written Language: The Selected Works of Kenneth S. Goodman and Yetta M. Goodman. USA: Routledge.

Gregory, G. H., \& Herndon, L. E. (2010). Differentiated Instructional Strategies for the Block Schedule. United States: Corwin Press.

len, L. K., Yunus, M. M., \& Embi, M. A. (2017). Build Me Up: Overcoming Writing Problems Among Pupils in A Rural Primary School in Belaga, Sarawak, Malaysia. Jurnal Pendidikan Humaniora, 5(1), 1-7. doi: 10.17977/um030v5i12017p001

Jusun, K. D. \& Yunus, M. M. (2016). The Effectiveness of Using Sentence Makers in Improving Writing Performance among Pupils in Lubok Antu Rural Schools. International Conference on Education, 469-475.

Krashen, S. (1981). Second Language Acquisition and Second Language Learning. Oxford: Pergamon.

Lau, J. L., Anthony, E. A., \& Yunus, M. M. (2019). Teaching Present Continuous Sentence with Rainbow Tower in Rural Primary School. International Journal of Academic Research in Business and Social Sciences, 9(2), 538-544. doi: 10.6007/IJARBSS/v9-i2/5588

Li, K. L., \& Razali, A. B. (2019). Idea Sharing: Process-Based Approach to Writing in Malaysian English Education. PASAA, 58: 317-339.

Li, K. L., \& Yee, T. J. (2017). The Use of Colourful Semantics to Improve Sentence Construction in Writing Sentences among Year Four Pupils. Journal of English Education, 2(1), 43-50.

Ling, T. M., \& Mohamad, M. (2018). Effects of Tree Map in the Teaching of Sentence Construction among Upper Primary Pupils. International Journal of Innovative Research and Creative Technology, 4(6), 126-133.

Majid, A. H. A., Stapa, S. H., \& Keong, Y. C. (2015). Blended Scaffolding Strategies through

Facebook for Learning and Improving the Writing Process and Writing Performance. Journal of Social Sciences and Humanities, 12(4), 31-39.

May, T. M., \& Said, N. E. M. (2019). Effects of writing kit innovation on ESL learners' sentence

construction. International Journal of Academic research in Business \& Social Sciences, 9(12), 292300. doi: 10.6007/IJARBSS/v9-i12/6724

Miin, W.P., Rou, L.Y. \& Yunus, M.M. (2019). Google Docs: Step by Step Sentence Construction for Primary School Marginal Passing Rate Pupils. Creative Education, 10(2), 237-245. doi: 10.4236/ce.2019.102019

Ministry of Education Malaysia. (2014). "Malaysia Education Blueprint."

New UPSR format sees big drop in straight A scorers. (2016, November 18). The Star. https://www.thestar.com.my/news/nation/2016/11/18/new-upsr-format-sees-bigdrop-in-straight-a-scorers/

Piaget, J. (1964). Development and learning in R.E. Kepple \& V.N Rockcastle (Eds) Piaget Rediscovered (pp.7-20).

Saed, H. A., \& AL-Omari, H. A. (2014). The Effectiveness of a Proposed Program Based on a Mind Mapping Strategy in Developing the Writing Achievement of Eleventh Grade EFL Students in Jordan and their Attitudes Towards Writing. Journal of Education and Practice, 5(18), 88-109. 
Sahathevan, E. N., \& Yamat, H. (2020). Learning Simple Sentence Construction Using Colourful Jenga Blocks. International Journal of Academic Research in Progressive Education \& Development, 9(1), 1-14. doi:10.6007/IJARPED/v9-i1/6824

Singh, G. K. H. (2014). Use of Process Writing to Enhance Writing Abilities among Year 5 Pupils. Retrieved from http://www.fp.utm.my/epusatsumber/pdffail/ptkghdfwp2/gurminderkau rmp101511d2014ttp.pdf

Taheri, M. (2014). The Effect of Using Language Games on Vocabulary Retention of Iranian Elementary EFL Learners. Journal of Language Teaching and Research, 5(3), 544-549.

Tarantino, K., McDonough, J., \& Hua, M. (2013). Effects of Student Engagement with Social Media on Student Learning: A Review of Literature. The Journal of Technology in Student Affairs, 42.

https://www.researchgate.net/publication/280079702_Effects_of_student_engagemen t_with_social_media_on_student_learning_A_review_of_literature

Toikka, T. (2016). Have a Break, Move and Learn Better: A Material Package for Introducing More Kinaesthetic Exercises into Upper Secondary School English Classes. Retrieved from https://jyx.jyu.fi/bitstream/handle/123456789/50014/1/URN\%3ANBN\%3 Afi\%3Ajyu-201605312789.pdf

Vygotsky, L. (1978). Interaction between learning and development of children 23(3): 34-41.

Walker-Gleaves, C., \& Waugh, D. (2017). Looking After Literacy - A Whole Child Approach to Effective Literacy Interventions. London: SAGE Publications Ltd.

Yaccob, N. S., \& Yunus, M. M. (2019). Language Games in Teaching and Learning English Grammar: A Literature Review. Arab World English Journal, 10(1), 209-217. doi: 10.24093/awej/vol10no1.18 